\title{
AMPUTEE REHABILITATION- A QUESTION OF TIME
}

BERNICE KEGEL, B.Sc. Physio. (Rand), R.P.T.

A survey of 127 patients seen at the University of Chicago over the past three years is presented in an attempt to discover and break down the length of time involved in amputee rehabilitation as well as the results achieved.

\section{MATERIALS AND METHOD}

During the past three years the University of Chicago has seen 127 patients with a total of 152 amputations. All the patients were seen at the Amputation Clinic, some on a consultative basis many years after completion of rehabilitation and some during rehabilitation. The University of Chicago is primarily an acute care facility. All Surgery and Physical Therapy were not necessarily achieved at this facility. Factors considered included age, sex, level of amputation, aetiology for amputation, and associated medical problems complicating rehabiltation. The survey was retrospective in design rather than experimental. In this way, personal bias is reduced. Data collected were subjected to analysis. Variations in total case numbers are related to either absence of data from the medical charts, or rehabilitation which is still in progress.

\section{RESULTS}

Age

The patients' ages ranged from birth to 90 years with a mean of 54,2 years. Twenty-eight per cent of the patients' were in the seventh decade of life at the time of amputation. Fifteen patients in this group have since expired. Period of time transpired between amputation and death ranged from three weeks to 23 years.

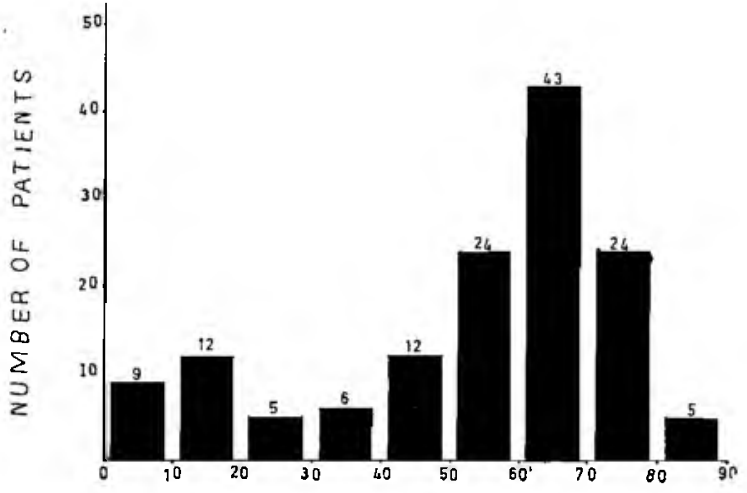

AGE AT TIME OF AMPUTATION
Sex

Patients studied included 51 females and 76 males.

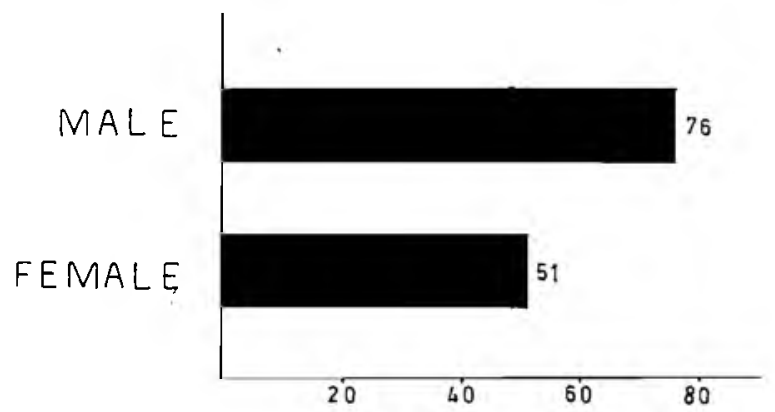

Figure 2: Sex distribution

\section{Level of Amputation}

There were 97 below knees amputees, 45 above knee amputees and 10 upper extremity amputees. Statistical differences between left and right sided involvement were insignificant.

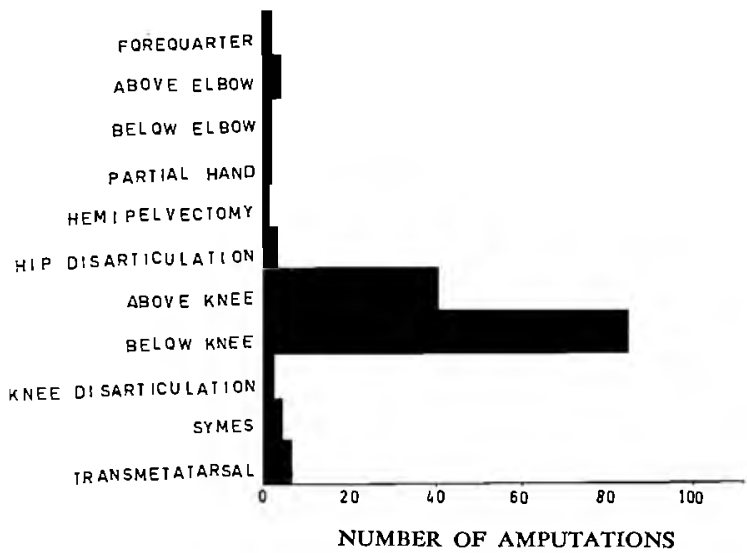

Fig. 1: Age at time of Amputation

Figure 3: Detailed Breakdown of Level of Amputation 


\section{Cause for Amputation}

Seventy-two per cent of the amputations were done due to vascular problems. Of the 99 vascular amputations, 56 patients had diabetes as well. Nine per cent of the amputations were done for tumours which included Giant Cell Lymphoma, Chondrosarcoma, Synovial Sarcoma, Amelanotic Malignant Melanoma, Fibrosarcoma, Squamous Cell Carcinoma and Rhabdomyosarcoma. Trauma, $10 \%$ included burns, gunshot wounds, motor vehicle accidents, train and motor cycle accidents as well as multiple fractures. Five per cent of the amputations were done for infection, mainly osteomyelitis. Very few congenital amputations were seen, probably because most children are referred to specialised Juvenile Amputee Clinics.

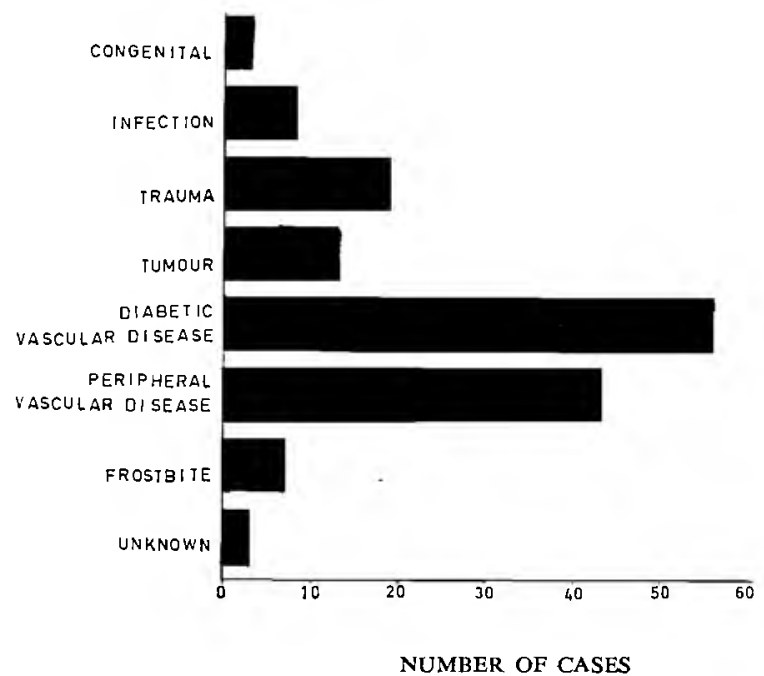

Figure 4. Cause of Amputation

Associated Medical Problems Complicating Rehabilitation Bearing in mind that the major reason for amputation was vascular insufficiency, and remembering that this is usually a generalised condition, the same fact limits rehabilitation. Thirty-one per cent of the patients had cardiovascular problems including Myocardial Infarction, Cerebrovascular accidents, Congestive Heart Failure and Hypertension. Seven per cent had poor vision or blindness. Twelve per cent had delayed wound healing, and $6 \%$ developed contractures. Other factors contributing to delayed rehabilitation were Rheumatoid Arthritis, Psoriasis, Bony Overgrowth and profound weight changes.

Length of Time Between Amputation and Prescription Ninety-one patients were followed up. Length of time varied from one month to 36 months with a mean of four months.

\section{Type of Prescription}

Seventy-one per cent of the below knee amputees were fitted with patella tendon bearing total contact sockets with soft leather liners, supra condylar straps, waist belt, and sach feet. Fourteen per cent were fitted with patella tendon supracondylar prostheses and $15 \%$ had the older plug fit with thigh lacers. The above knee amputees were fitted with quadrilateral total contact sockets, $50 \%$ with suction, $50 \%$ without. The majority had bock safety knees. Three patients had Mauch S.N.S. hydraulic knees.

\section{Time Elapsed Between Prosthetic Prescription and Delivery}

Seventy-four patients were followed up. Time elapsed ranged from one month to 12 months with a mean of $2 \frac{1}{2}$ months.

\section{Length of Training}

Sixty-eight patients were trained at this facility. Most patients were treated as outpatients, being seen 2-3 times per week. Training time varied from 2 weeks to 7 months with a mean of 1,9 months. Two months on the average was required to prosthetically train a below knee amputee, and 3 months for an above knee amputee.

\section{Level of Independence Reached}

Eighty-nine patients were reviewed. Twenty-five per cent of all patients walked without any assistive device and $42 \%$ required only one cane. Only $2 \%$ of the patients were wheelchair bound.

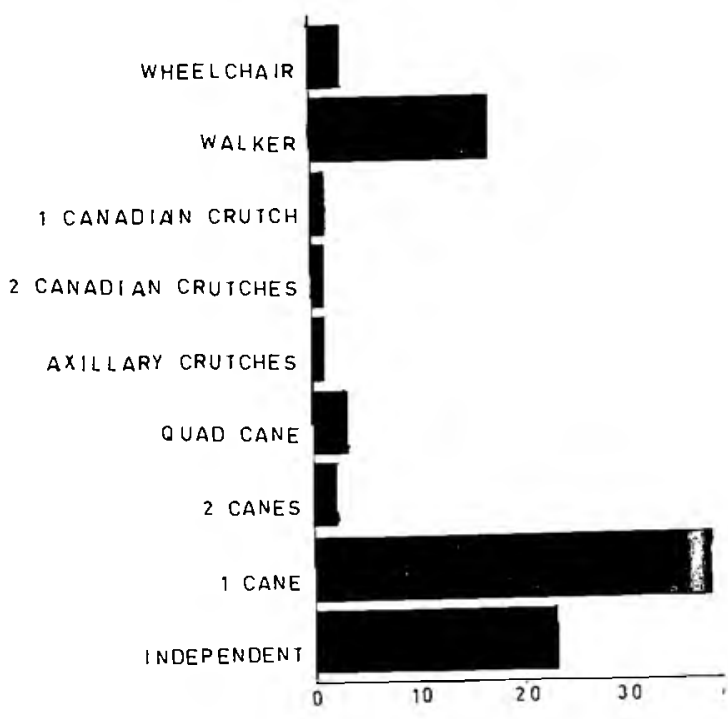

NUMBER OF PATIENTS

Figure 5: Level of Independence Achieved

Total Time Involved

On the average it takes eight months for completion of rehabilitation from time of amputation to time of discharge from Physiotherapy. Kerstein (1974) reports six months, but does not state how often patients were seen for treatment.

Breakdown of Length of Time from Amputation to Prescription, Length of Training, Independence Attained according to Sex, Age, and Aetiology

For the purpose of simplicity, independent ambulation was considered of those patients walking without any external aid, or using just a straight cane. Assisted ambulation was considered anything from two canes to a walker. 
Table I:

\begin{tabular}{|c|c|c|c|c|}
\hline & $\begin{array}{l}\text { Time From } \\
\text { Amputation to } \\
\text { trescription }\end{array}$ & $\begin{array}{l}\text { 1. ength of } \\
\text { Training }\end{array}$ & $\begin{array}{l}\text { Independent } \\
\text { Ambulation }\end{array}$ & $\begin{array}{c}\text { Ambulation } \\
\text { with } \\
\text { Assistance }\end{array}$ \\
\hline $\begin{array}{l}\text { 1. Sex } \\
\text { Male } \\
\text { Female }\end{array}$ & $\begin{array}{l}3 \text { mor:ths } \\
4,6 \text { months }\end{array}$ & $\begin{array}{l}1.8 \text { months } \\
1.8 \text { months }\end{array}$ & $\begin{array}{l}84 \% \\
50 \%\end{array}$ & $\begin{array}{l}16 \% \\
50 \%\end{array}$ \\
\hline $\begin{array}{l}\text { Age } \\
0-30 \text { years } \\
30-60 \text { years } \\
60 \text { and up }\end{array}$ & $\begin{array}{l}2 \text { months } \\
3 \text { months } \\
3 \text { months }\end{array}$ & $\begin{array}{l}1.9 \text { months } \\
1.6 \text { months } \\
1.8 \text { months }\end{array}$ & $\begin{array}{l}91 \% \\
56 \% \\
69 \%\end{array}$ & $\begin{array}{r}9 \% \\
44 \% \\
31 \%\end{array}$ \\
\hline $\begin{array}{l}\text { 3. Cause } \\
\text { Frostbite } \\
\text { Peripheral } \\
\text { Vascular }\end{array}$ & $\begin{array}{l}\text { No information } \\
3,5 \text { months }\end{array}$ & $\begin{array}{l}\text { No information } \\
1.9 \text { months }\end{array}$ & $\begin{array}{c}100 \% \\
63 \%\end{array}$ & $\begin{array}{r}0 \% \\
37 \%\end{array}$ \\
\hline $\begin{array}{l}\text { Disease } \\
\text { Diabetes }\end{array}$ & 3.4 months & 1.6 months & $65 \%$ & $35 \%$ \\
\hline $\begin{array}{l}\text { Mellitus } \\
\text { Tumour } \\
\text { Trauma } \\
\text { Infectios } \\
\text { Congenital }\end{array}$ & $\begin{array}{c}4 \text { months } \\
5 \text { months } \\
3.5 \text { months } \\
\text { No information }\end{array}$ & $\begin{array}{c}1,2 \text { months } \\
2.5 \text { months } \\
1 \text { month } \\
\text { INore }\end{array}$ & $\begin{array}{l}66 \% \\
90 \% \\
50 \% \\
100 \%\end{array}$ & $\begin{array}{l}44 \% \\
10 \% \\
50 \% \\
0 \%\end{array}$ \\
\hline
\end{tabular}

\section{Discussion}

Eight months is a long time for any patient to wait to be fully ambulant again. Efforts should be directed to reduce that time. Length of time from amputation to prescription appears unaffected by age, sex, and criginal aetiology for amputation. The only way to decrease this time is improved wound healing and shaping of the residual limb. Several research programmes are under way attempting to make improvements in this area. Two-and-a-half months from prosthetic prescription to delivery is indeed excessive. Actual fabrication of the prosthesis takes only a few days. This is due in part to slowness of third party payment. The major reason for this delay appears purely administrative in nature and could probably be decreased. At this facility a private prosthetic company not situated within the actual hospital was utilized. Perhaps by having a certified pros-

\section{THE PRINCIPLE OF PHYSIOTHERAPY WORKSHOPS}

The concept of Physiotherapy Workshops was first put to use by the Obstetric Association and has been used successfully in recent months by the S.A.S.P. Northern Transvaal Branch.

A Workshop takes the form of an informal, roundtable gathering of physiotherapists at which both theoretical and practical aspects of a particular subject are thoroughly discussed and demonstrated. The subject is introduced by one or two more experienced members, after which any member may put forward ideas on the subject and demonstrate the technique forthwith. A treatment mat, plinth, apparatus or machine under discussion can be displayed and used at such a workshop.

The Workshop leader sums up at the end and defines areas of uncertainty which can be researched before a later, report-back workshop. A panel of experts may also be invited to guide discussion.

The aims of Physiotherapy Workshops can be summarised as follows:

1. to enable physiotherapists to interchange ideas and learn from one another in an informal, practical atmosphere; thetist on the staff of the Rehabilitation Medicine Department, this time lag could be significantly reduced.

Length of training averaged at 1,9 months, regardless of age, sex, or cause of amputation. Results presented are those for patients treated on an out-patient basis. Perhaps having the patient admitted to the hospital for shorter, more intensive rehabilitation would be the solution. lnvestigation into this matter should be instigated. Also interesting to note is that it takes approximately the same length of time to train a 20-year-old as it does an 80-year-old. The reason for this is probably that the 20-year-old is pushed to greater degiees of perfection, and taught many more things. The fact that $69 \%$ of patients over 60 years of age attained independence is impressive.

As can be seen from the independence levels achieved, in spite of age and poor vasculature, prosthetic training is obviously worth the effort. It is a question of level of achievement versus price in time! Continued emphasis is required to decrease the time involved.

\section{Summary}

A group of amputees seen at the Amputation Clinic of the University of Chicago are reviewed, with special reference to breakdown of length of time involved in completing rrehabilitation, and independence levels achieved. Attempts were also made to see if age, sex and cause for initial amputation played any role in determining length of training or functional ability achieved.

\section{Acknowledgements}

I would like to thank the Director and staff of the Physical Thelapy Department at the University of Chicago for their advice, criticism and assistance in accumulation of data.

\section{References}

1. Kerstein, M. D.; Zimmer, H.; Dugdale, F. E.; Lerner, E.; "Amputation of the Lower Extremity; A Study of 194 Cases". Arch. Phys. Med. Oct. 1974.
2. to define controversial or uncertain areas of a subject requiring research, and therefore

3. to stimulate interest in research;

4. to create an opportunity for presenting and discussing available research literature which is otherwise often overlooked.

The Workshop evenings are characterised by lively comment, pauses of furious concentration and, needless to say, frequent bantering which, while ensuring a headache or two for the Workshop leader, makes the evening both educational and enjoyable.

Subjects dealt with so far were hemiplegia and low back pain. The latter proved too vast an area, as experts on the various causes spoke and after $2 \frac{1}{2}$ hours the Chairman had to interrupt lively and interested discussion and promise a second session!

Physiotherapy Workshops need not replace the more conventional lecture form of Branch meetings, but do provide a refreshing variation on many an old theme. Workshops have, however, proved to be very popular with all categories of members and attendance at these has increased both in numbers and active participation. 